\author{
UNITED STATES \\ DEPARTMENT OF THE INTERIOR
}

GEOLOGICAL SURVEY

Technique for Estimating the

Magnitude and Frequency of Missouri Floods

By

Leland D. Hauth

Prepared in cooperation with

the Missouri State Highway Department

and

U.S. Department of Transportation,

Federal Highway Administration

The opinions, findings, and conclusions expressed

in this publication are not necessarily those of the Federal Highway Administration

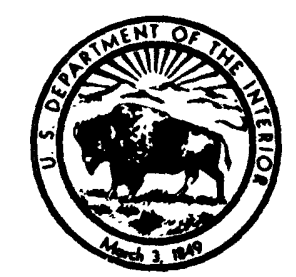

Open-file report

Rolla, Missouri

1974

$91-89$

Because of renewed interest in this report, it was reissued during 1991. 
Abstract-n- 1

Introduction- 1

Estimating technique- 3

Limitations of equations- 5

Analysis- 17

Basic data- 17

Determination of basin characteristics--- 17

Determination of estimating relations- 17

Summary-- 18

References- 19 
Figure 1. Graphical solution of the 2-year equation--- 6

2. Graphical solution of the 5-year equation---- 7

3. Graphical solution of the 10-year equation--- 8

4. Graphical solution of the 25-year equation--- 9

5. Graphical solution of the 50-year equation--- 10

6. Graphical solution of the 100-year equation-- 11

7. Map showing location of gaging stations used to determine flood-frequency relationships--non-

TABLES

Table 1. Summary of regression equations- 4

2. Flood-frequency data for streamgaging stations in Missouri- 13 
FACTORS FOR CONVERTING ENGLISH UNITS TO

INTERNATIONAL SYSTEM (SI) UNITS

The following factors may be used to convert the English

units published herein to the International System of Units (SI).

Multiply English units

By

To obtain SI units

Length

Feet $(\mathrm{ft})$

0.3048

Metres (m)

Square miles $\left(\mathrm{mi}^{-2} \mathrm{I}\right.$

2.590

Square kilometres $\left(\mathrm{km}^{2}\right)$

Miles (mi)

1.609

Kilometres $(\mathrm{km})$

Feet per mile ( $\mathrm{ft} / \mathrm{mi}$ )

0.1893

Metres per kilometre $(m / k)$

Flow

Cubic feet per second

0.02832

Cubic metres per

$\left(\mathrm{ft} \mathrm{t}^{3} / \mathrm{s}\right)$ second $\left(\mathrm{m}^{3} / \mathrm{s}\right)$ 


\section{Technique for Estimating the \\ Magnitude and Frequency of Missouri Floods}

By Leland D. Hauth

ABSTRACT

A technique is presented for estimating the magnitude and frequency of Missouri floods. For 152 gaged sites the magnitudes of floods having recurrence intervals of 2 to 100 years are provided in tables. For ungaged sites, regression relations are presented that allow the estimation of flood magnitudes from a knowledge of the upstream drainage area and the average main-channel slope. The estimating equations are provided in a graphical form for the convenience of the user.

\section{INTRODUCTION}

The purpose of this report is to provide techniques for estimating the magnitude and frequency of flooding at sites in Missouri. Previous reports, Searcy (1955), Patterson (1964), Patterson and Gamble (1968), Matthai (1968), Sandhaus and Skelton (1968), and Skelton and Homyk (1970), have presented methods for estimating flood magnitudes for various recurrence intervals. Each method has been developed on the basis of a limited period of record or sample size and could be used with confidence only for drainage areas greater than $50 \mathrm{mi}^{2}\left(130 \mathrm{~km}^{2}\right)$. 
Relationships presented in this report were defined from an expanded data base by detailed analytical techniques and should provide flood estimates of increased reliability.

Because of the need for better definition of flood frequency covering all sizes of drainage areas 10.1 to $14,000 \mathrm{mi}^{2}$ or 0.26 to $36,300 \mathrm{~km}^{2}$ ) in Missouri, an effort was made to use the limited information collected on small drainage areas (areas less than $10 \mathrm{mi}^{2}$ ) so that when small-area data were included in a statewide data matrix, flood-frequency relationships could be defined for the full range of drainage areas.

A rainfall-runoff model developed by Dawdy, Lichty, and Bergmann (1972) was used to extend short records on small drainage areas so that flood magnitude and frequency with recurrence intervals as high as 100 years could be defined. Flood-frequency curves at each data site, based on synthesized peaks from the rainfall-runoff model for small drainage areas and observed peaks for the larger drainage areas, were defined by fitting the Pearson Type III distribution to the logarithms of the data as recommended by the Hydrology Committee, Water Resources Council (1967), Bulletin 15. Resulting flood magnitudes with recurrence intervals of $2,5,10,25,50$, and 100 years were related to drainage area and average main-channel slope in a regression analysis. 
For ungaged natural floodflow sites, flood magnitudes having recurrence intervals of $2,5,10,25,50$, and 100 years are computed by using appropriate values of the contributing drainage basin size and slope in the equations shown in table 1 or in the graphs of figures 1-6. Drainage area (A) in square miles, can be obtained by planimetering the area contributing surface flows to the site as outlined along the drainage divide on the best available topographic maps. Slope (S) in feet per mile, is the average slope between points 10, and 85 percent of the distance along the main-stream channel from the site to the basin divide. Distance is measured by setting draftsman's dividers at $0.1 \mathrm{mile}(0.16 \mathrm{~km})$ spread and stepping along the channel. The main channel is defined above stream junctions as the one draining the largest area. Elevation differences between the 10- and 85-percent points are divided by the distance between the points to evaluate the slope. 
Table 1.--Summary of regression equations

\begin{tabular}{|c|c|c|}
\hline $\begin{array}{c}\text { Frequency of flood } \\
\text { (years) }\end{array}$ & $\begin{array}{l}\text { Magnitude of flood } \\
\qquad\left(\mathrm{ft}^{3} / \mathrm{s}\right)\end{array}$ & $\begin{array}{c}\text { Standard error of } \\
\text { estimate } \\
\text { (percent) }\end{array}$ \\
\hline $2-\cdots \cdots$ & $53.5 A^{0.851 A^{-0.02}} s^{0.356}$ & 38.6 \\
\hline 5- - & $64.0 A^{0.886 A^{-0.02}} s^{0.450}$ & 34.7 \\
\hline $10-\cdots$ & $67.6 A^{0.905 A^{-0.02}} s^{0.500}$ & 34.5 \\
\hline 25- & $73.7 A^{0.924 A^{-0.02}} s^{0.542}$ & 35.0 \\
\hline 50- - - & $79.8 A^{0.926 A^{-0.02}} s^{0.560}$ & 33.3 \\
\hline $100 \ldots$ & $85.1 A^{0.934 A^{-0.02}} s^{0.576}$ & 33.3 \\
\hline
\end{tabular}

Examole:

Assume design of a hydraulic structure is desired at a point on a stream above which are $200 \mathrm{mi}^{2}\left(518 \mathrm{~km}^{2}\right)$ of drainage. The average main-channel slope is $6 \mathrm{ft} / \mathrm{mi}(1.14 \mathrm{~m} / \mathrm{km})$ and the design frequency desired is 50-year recurrence interval.

1. Solution of equation from table 1 .

$$
\begin{aligned}
Q_{50} & =79.8(200)^{0.926(200)^{-0.02}}(6)^{0.560} \\
& =18,000 \mathrm{ft}^{3} / \mathrm{s}\left(510 \mathrm{~m}^{3} / \mathrm{s}\right) .
\end{aligned}
$$


2. From figure 5 , read $200 \mathrm{mi}^{2}\left(518 \mathrm{~km}^{2}\right)$ along the ordinate and over to the $6 \mathrm{ft} / \mathrm{mi}(1.14 \mathrm{~m} / \mathrm{km})$ slope curve. Resulting flood peak,

$$
Q_{50}=18,000 \mathrm{ft}^{3} / \mathrm{s}\left(510 \mathrm{~m}^{3} / \mathrm{s}\right) \text {. }
$$

For gaged sites (see figure 7), flood magnitudes having recurrence intervals of $2,5,10,25,50$, and 100 years are shown in table 2. These flood magnitudes were defined by frequency analysis of abserved flood records for sites draining greater than $10 \mathrm{mi}^{2}$ $\left(26 \mathrm{~km}^{2}\right)$ and by frequency analysis of partially synthesized records for smaller streams. In general, the values of table 2 will provide the most reliable estimates of future flood characteristics.

\section{Limitations of Equations}

The flood-frequency equations in this report may be used to estimate magnitude and frequency of floods on most Missouri streams for drainage areas ranging from 0.1 to $14,000 \mathrm{mi}^{2}\left(0.26\right.$ to $\left.36,300 \mathrm{~km}^{2}\right)$, and slopes ranging from 1.0 to $300 \mathrm{ft} / \mathrm{mi}(0.19$ to $56.8 \mathrm{~m} / \mathrm{km})$. However, equations are not applicable for basins where manmade changes have appreciably changed the flow regimen or on main stems of the Mississippi River and Missouri River. Flood-frequency relations for the upper Mississippi River are presented by Patterson and Gamble (1968), and for the lower Mississippi River by Patterson (1964). Flood characteristics of the Missouri River below Sioux City, Iowa are presented by Matthai (1968). Equations given in this report do not apply to areas near the mouth of streams draining into larger rivers where backwater effect is experienced. Caution should also be taken when utilizing equations presented here for drainage areas less than $10 \mathrm{mi}^{2}$ $\left(26 \mathrm{~km}^{2}\right.$ ) which are located in the Lowlands region of Missouri. 


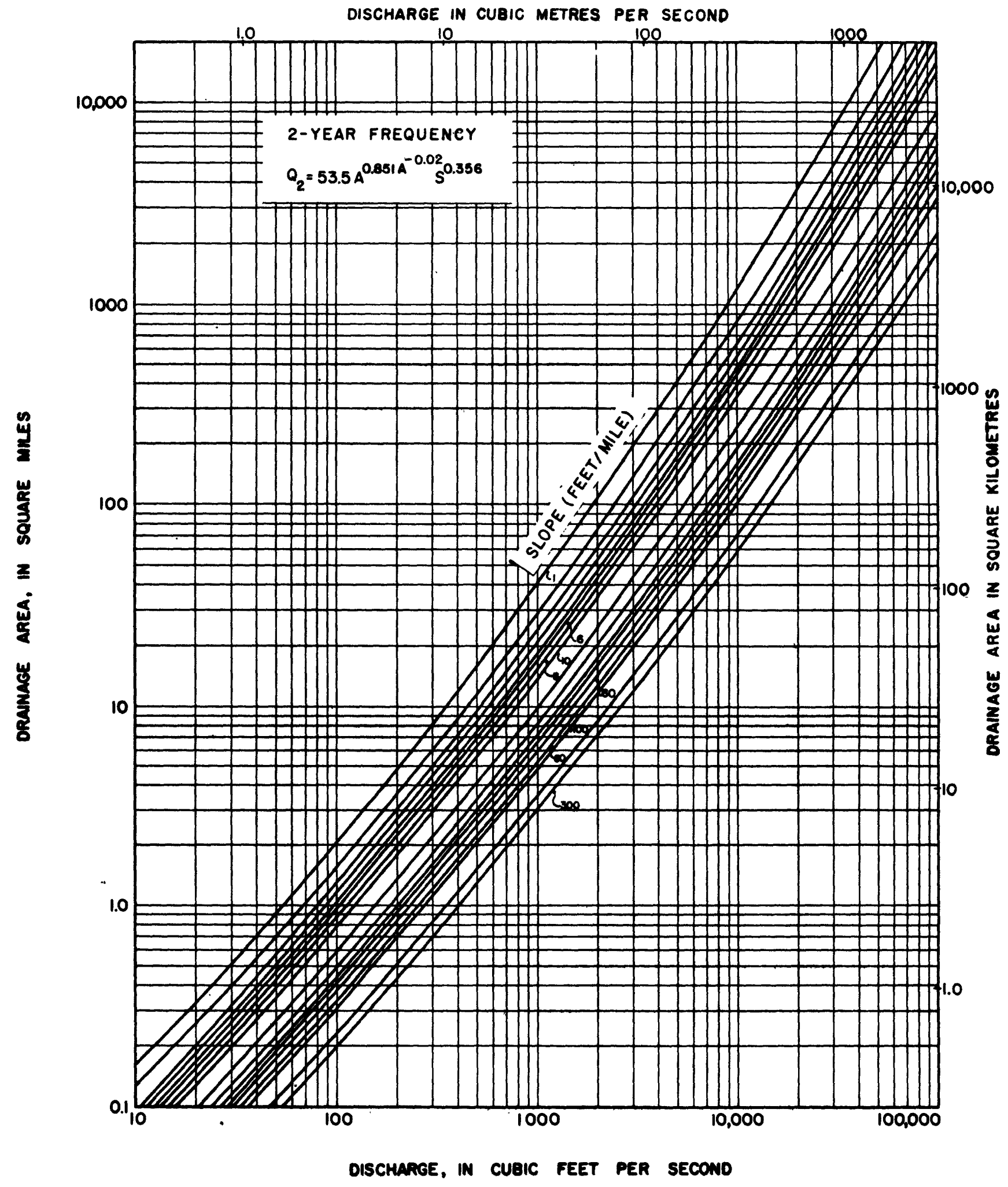

FIGURE 1. Graphical solution of the 2-year equation. 
discharge IN CUBIC METRES PER SECOND

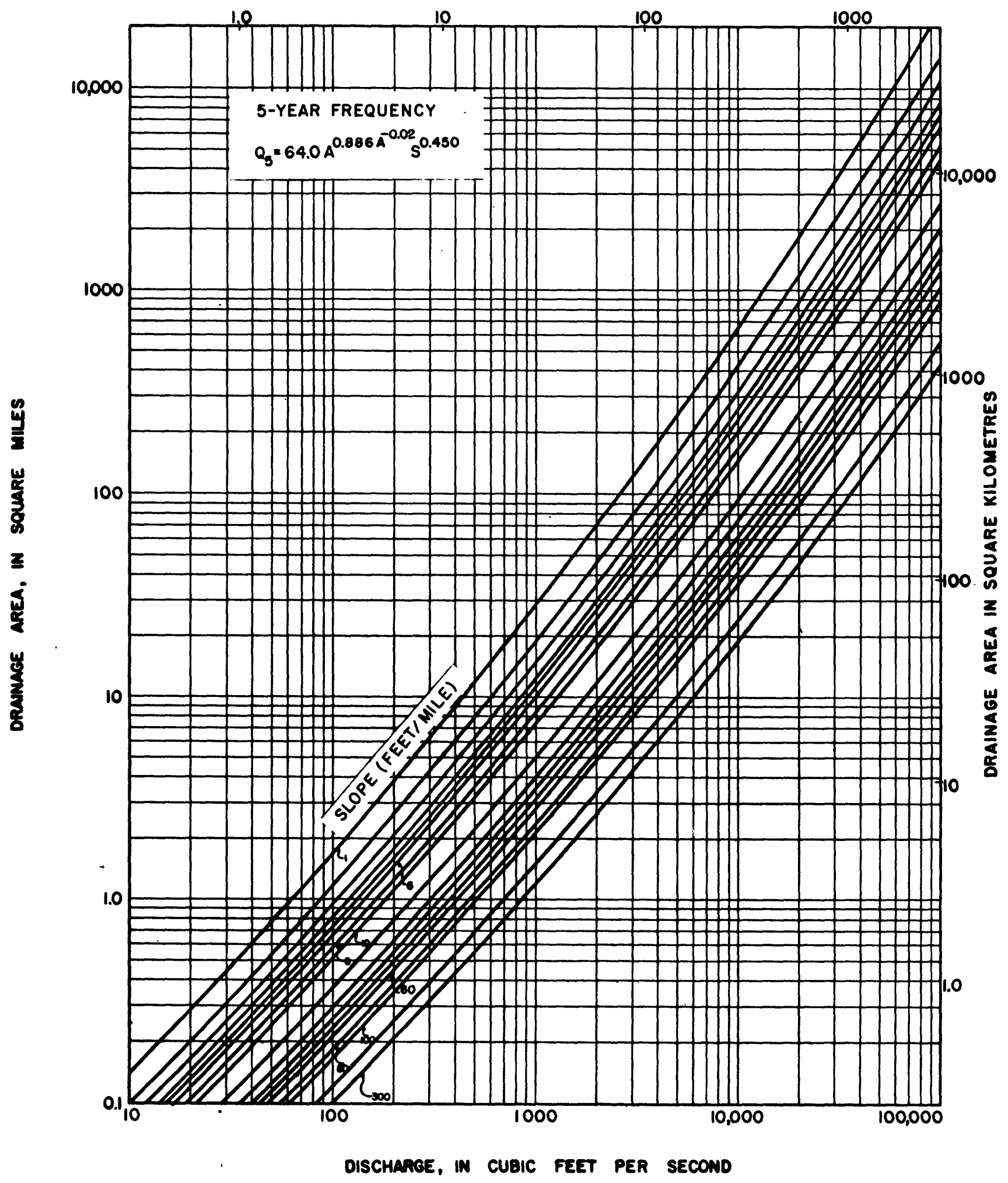

FIGURE 2 Grophicol solution of the 5-yeor equation. 


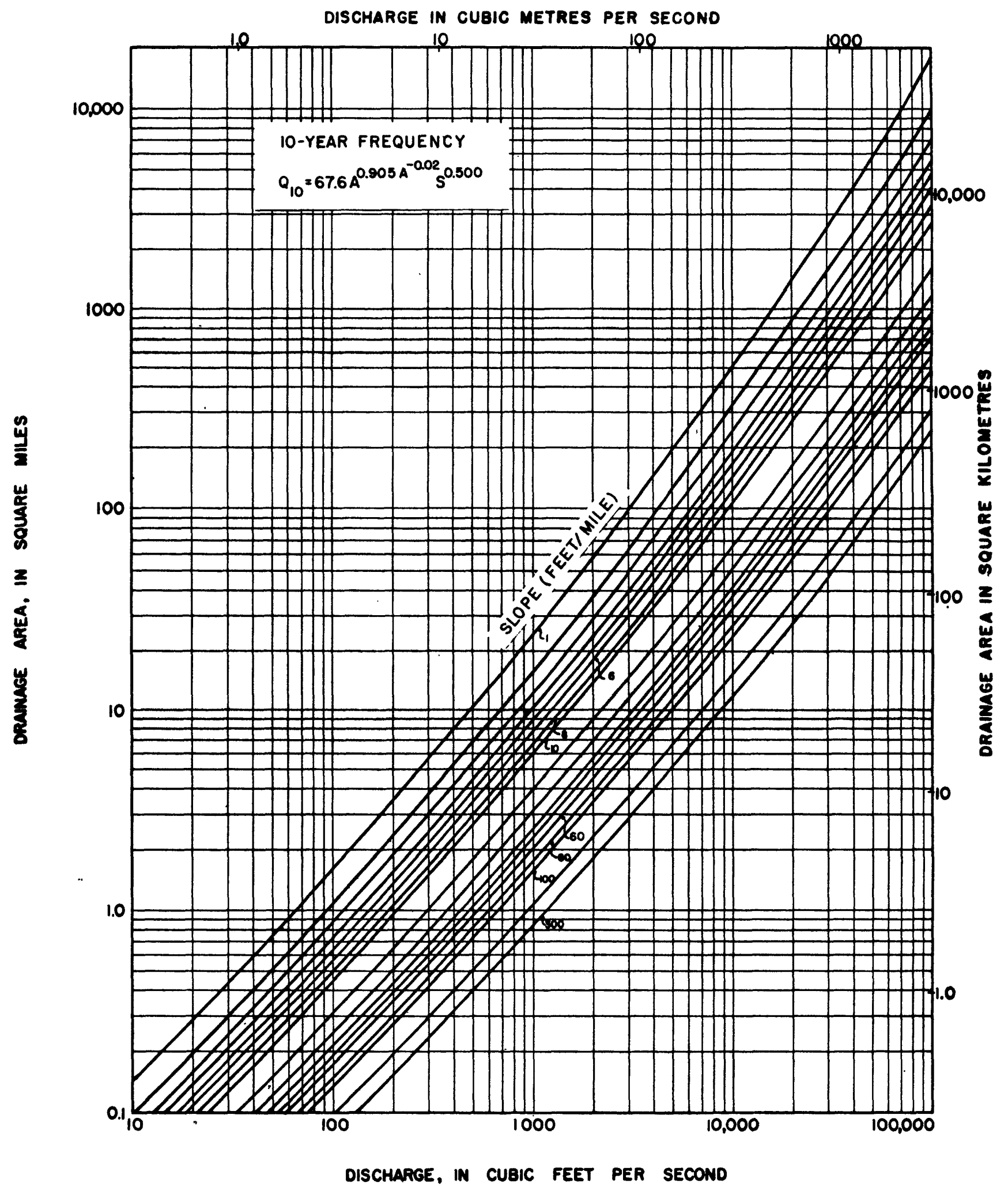

FIGURE 3 Grophical solution of the 10-year equation. 


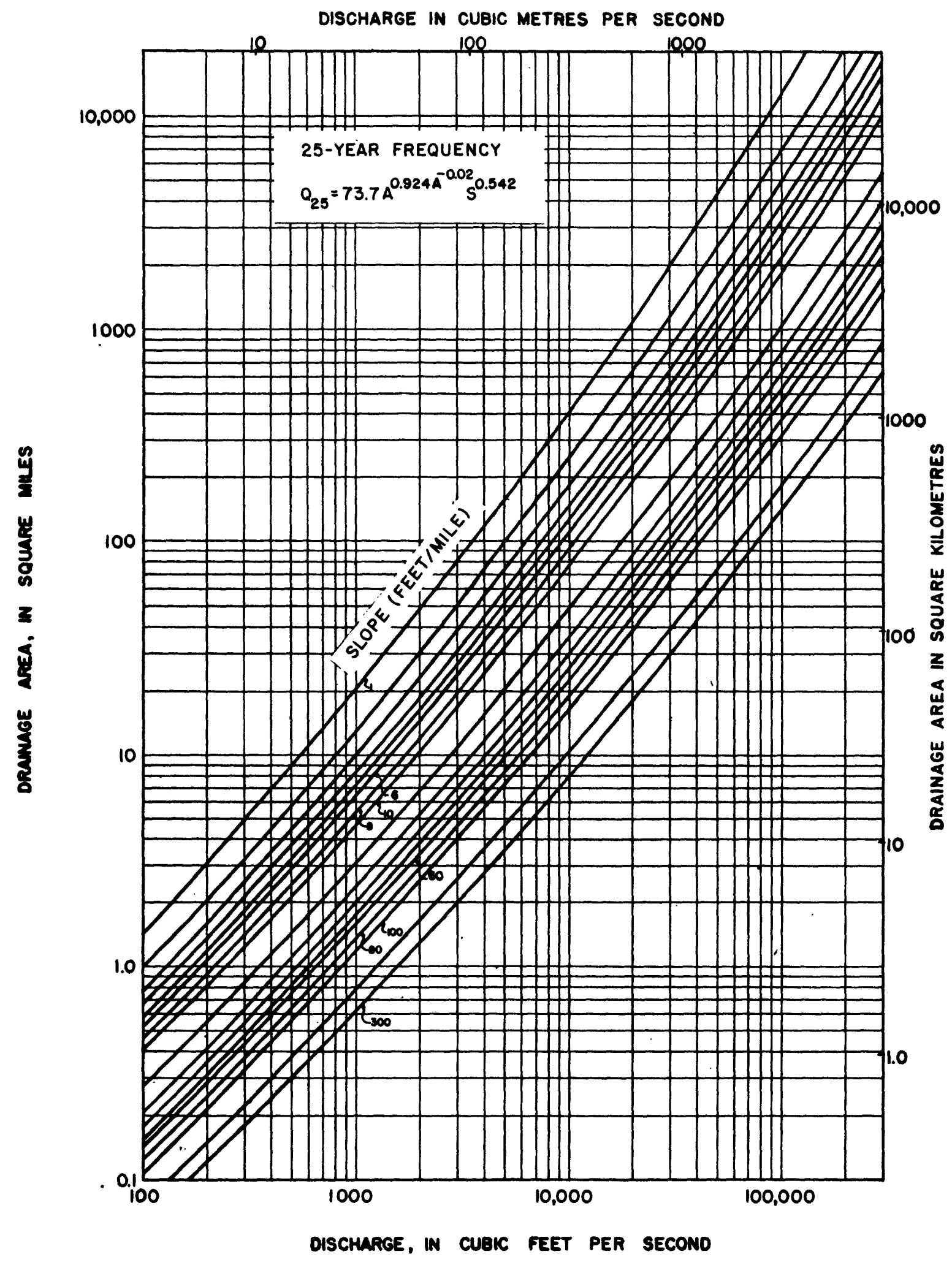

FIGURE 4 Grophical solution of the 25-year equation. 


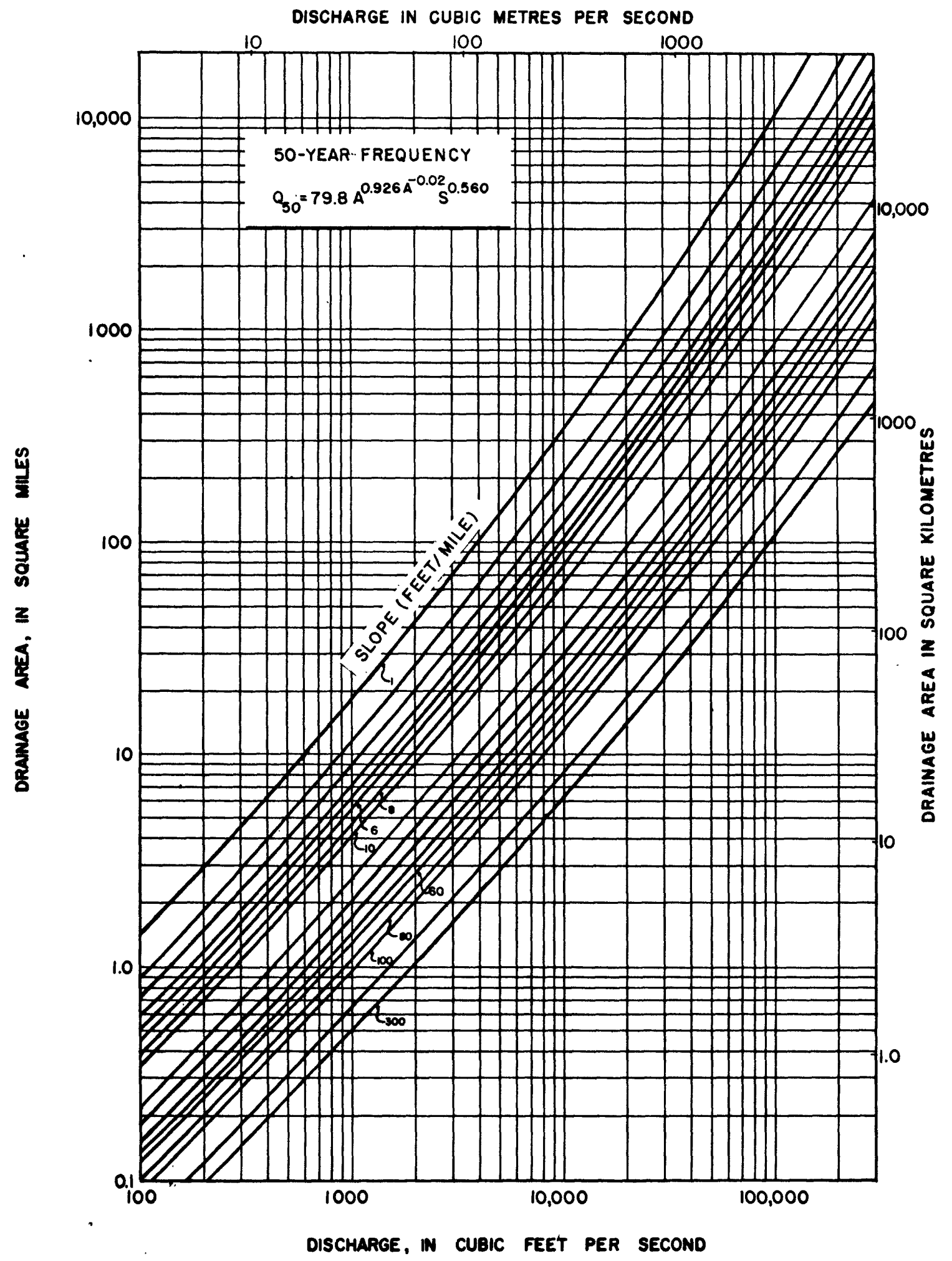

FIGURE 5 Grophical solution of the so-year equation. 


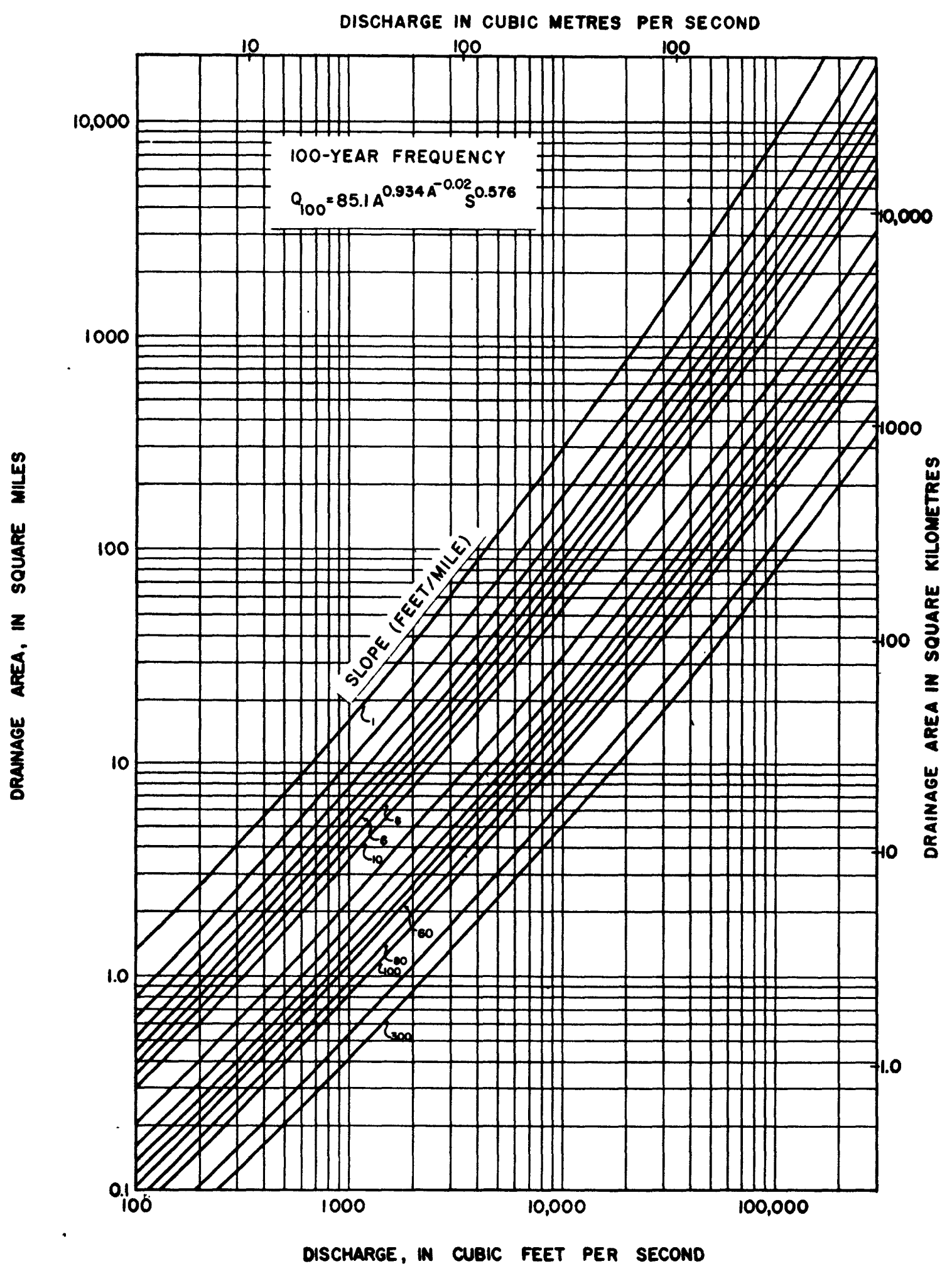

FIGURE 6. Graphical solution of the 100-year equation. 


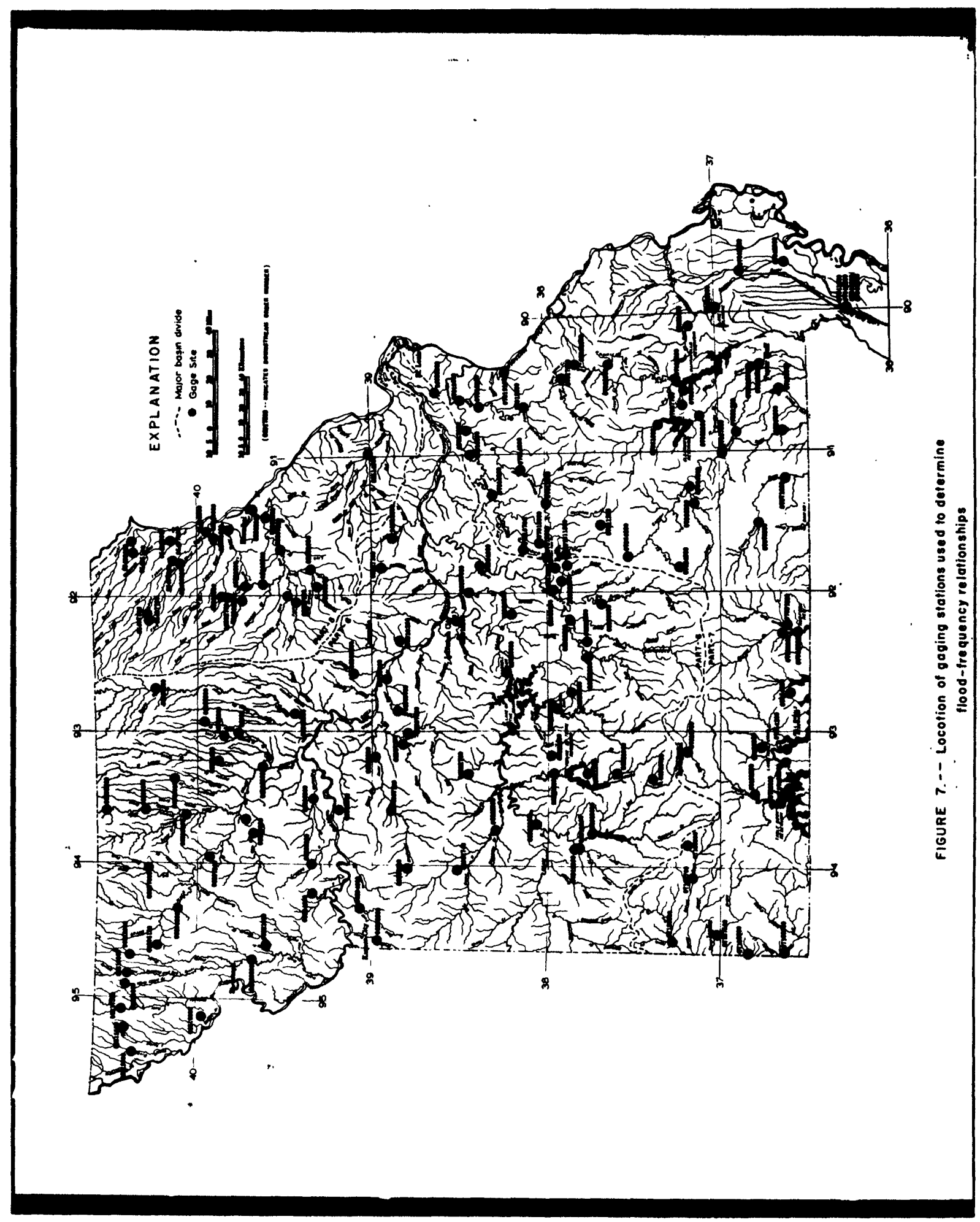




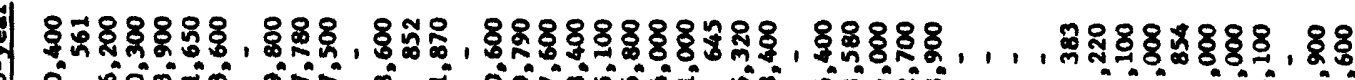

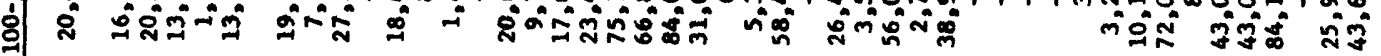

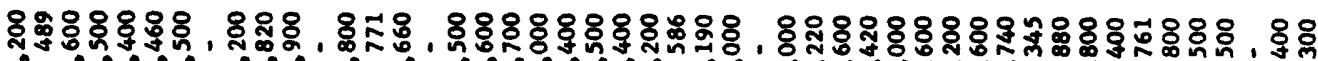

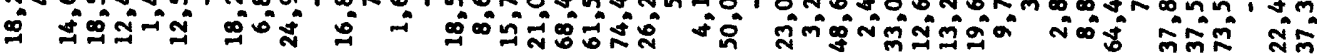

过

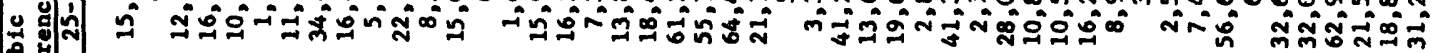

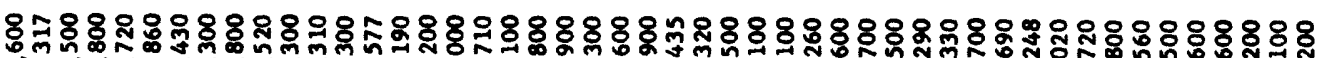

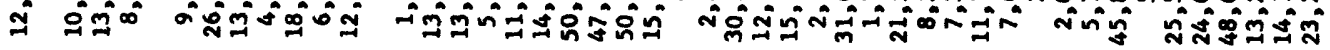

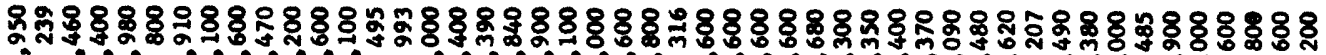

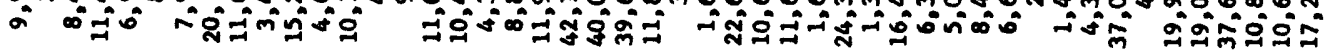

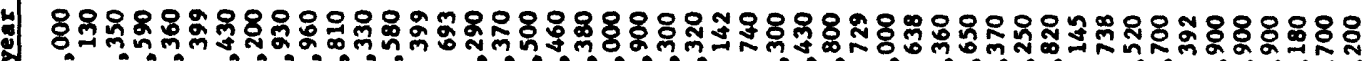

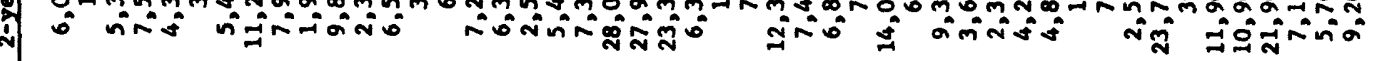

भำ

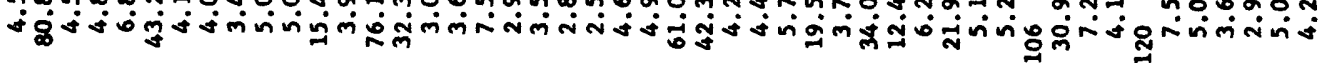

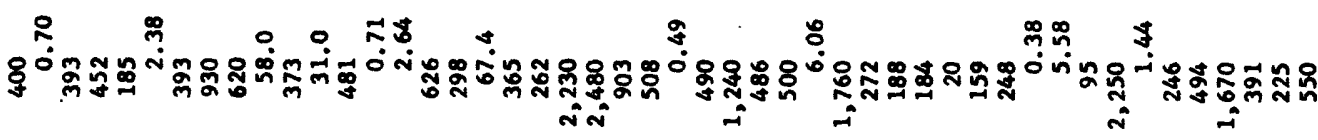

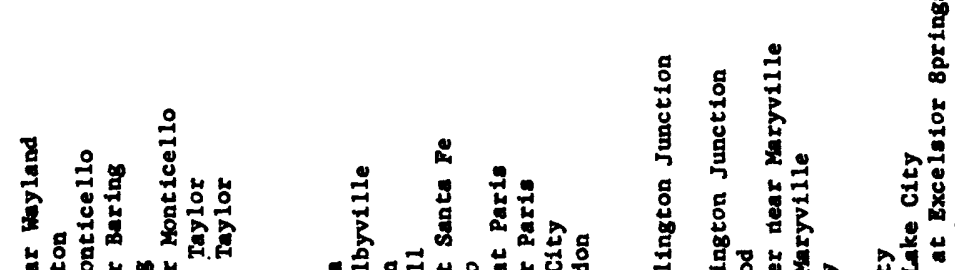

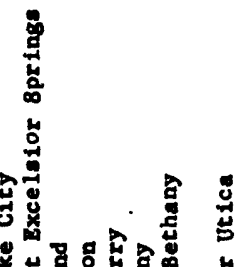

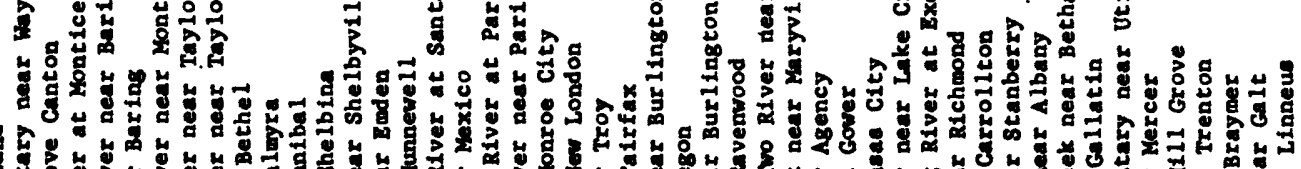
夏

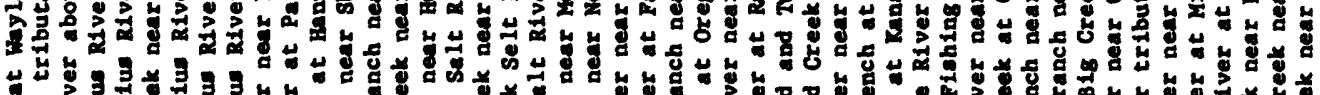

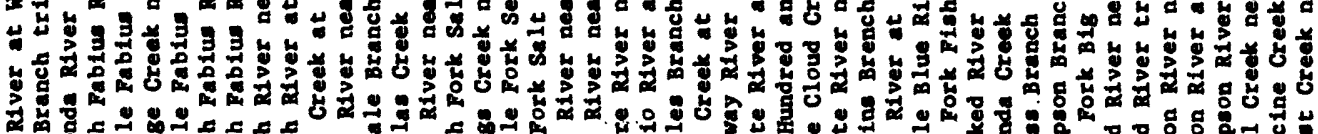

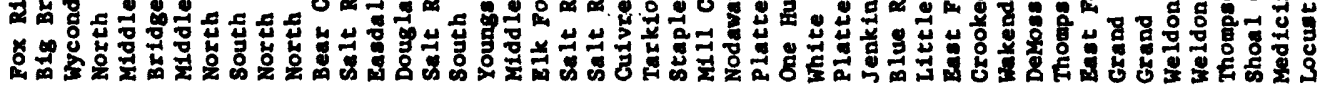

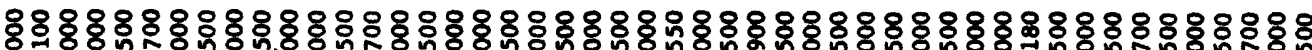




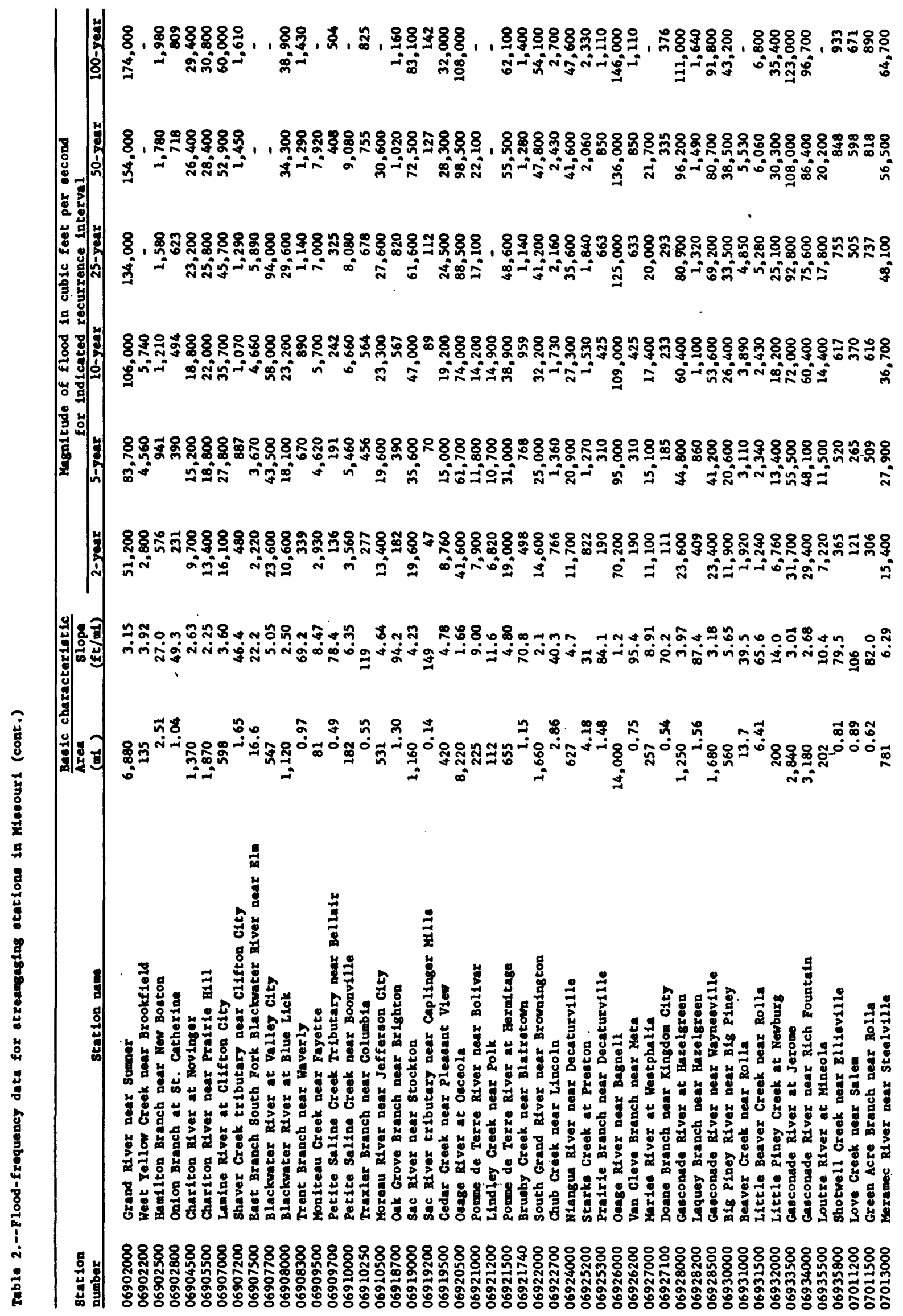




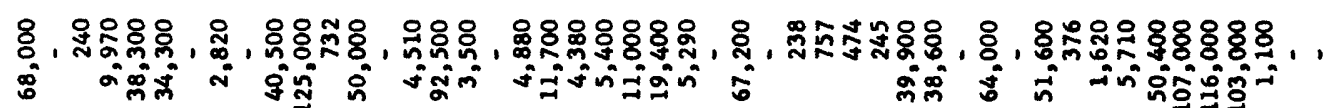

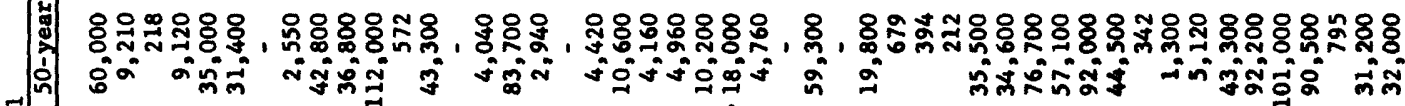

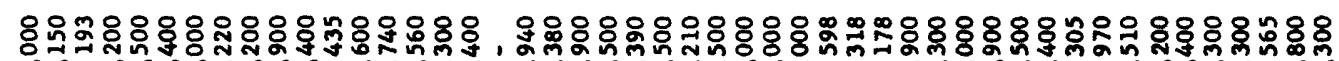

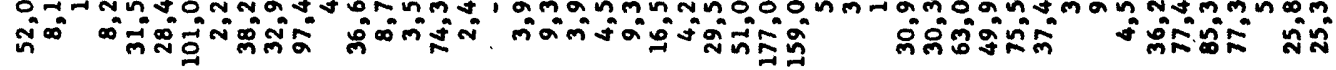

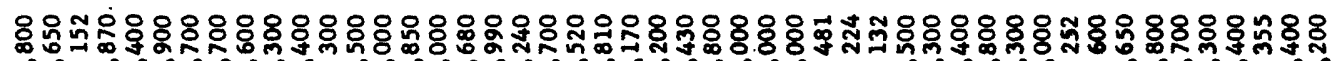

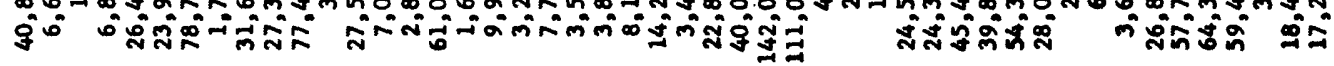

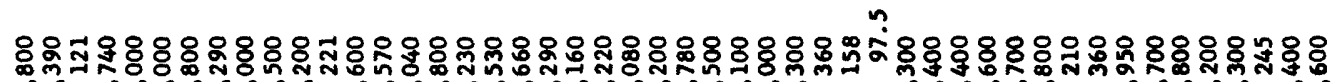

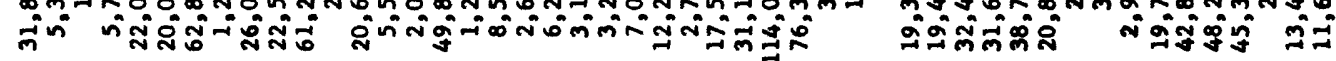

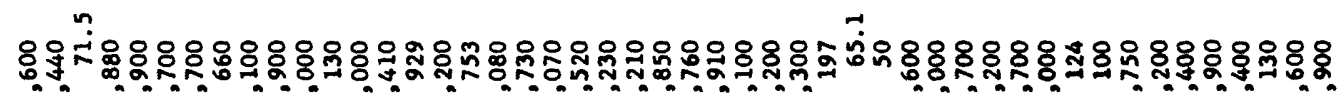

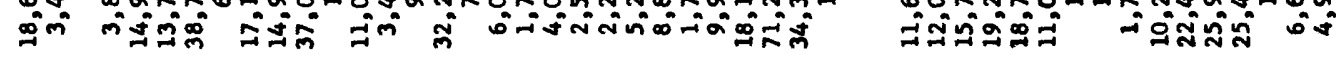

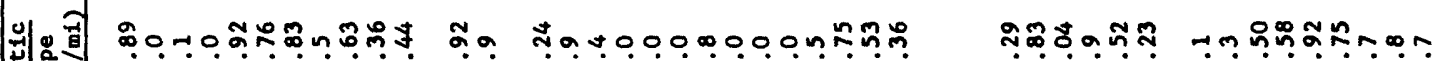

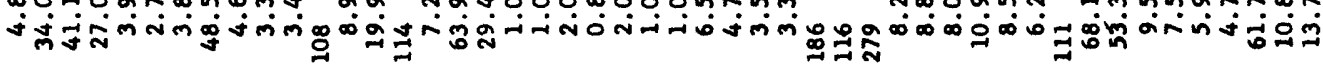

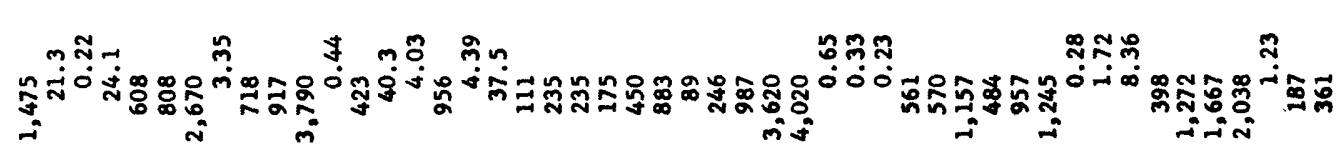

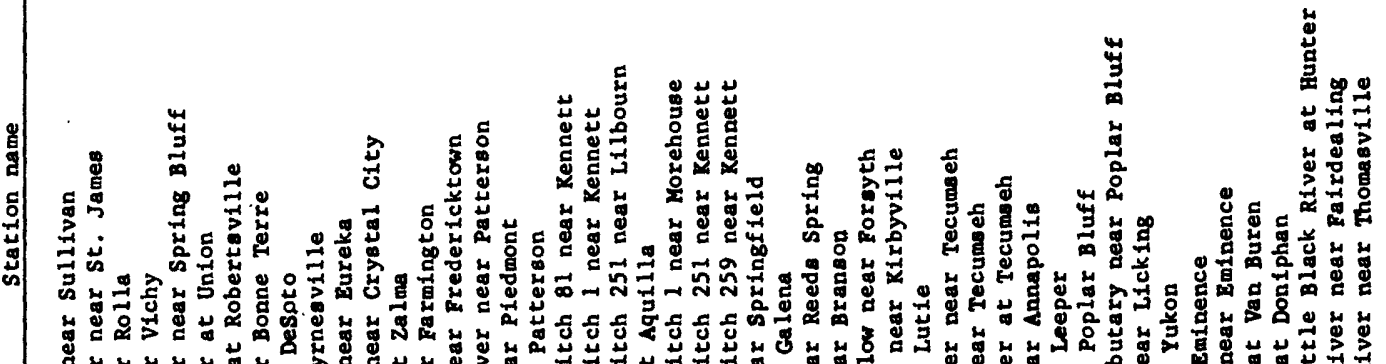

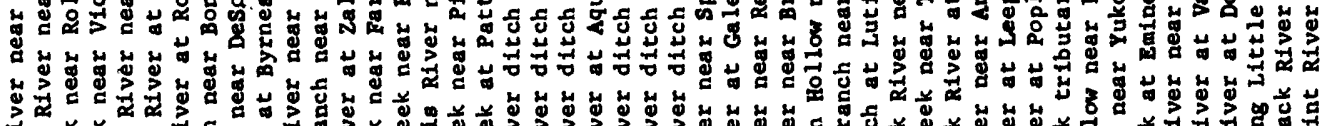

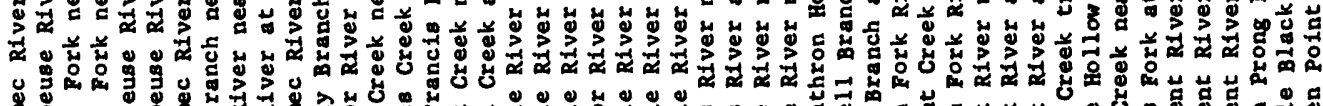

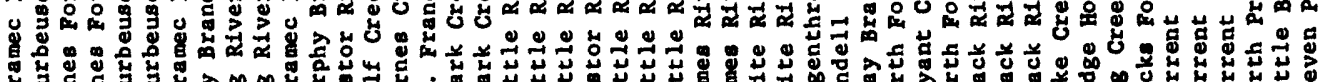

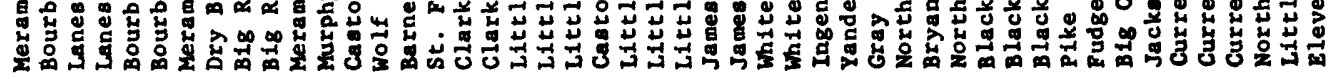




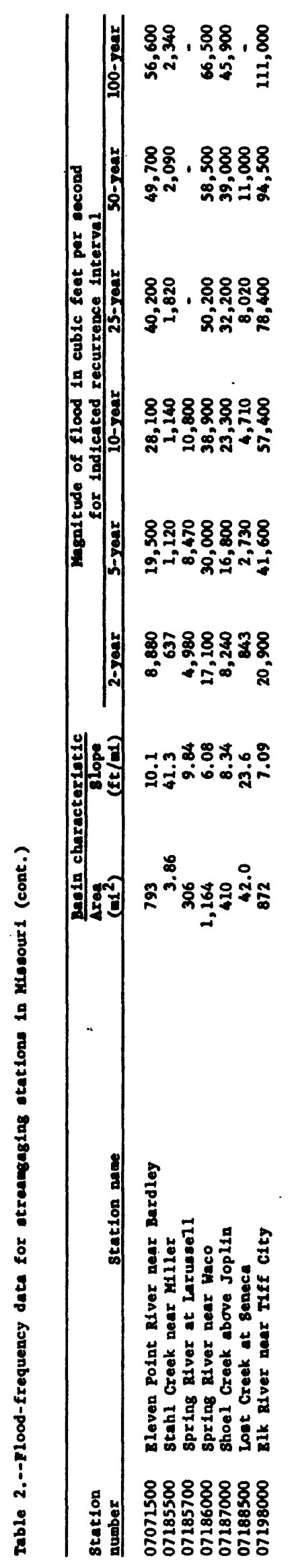


Basic Data

Streamflow and basin characteristics from a network of 152 stations were used in this analysis and are listed in table 2. Their distribution throughout the state is shown in figure 7. The data set does not contain information on small-area stations (drainage areas less than $10 \mathrm{mi}^{2}\left[26 \mathrm{~km}^{2}\right]$ ) with flat slopes as experienced in the Lowlands or Bootheel region due to the difficulty in establishing stage-discharge relationships. Drainage area sizes range from 0.1 to $14,000 \mathrm{mi}^{2}\left(0.26\right.$ to $\left.36,300 \mathrm{~km}^{2}\right)$.

\section{Determination of Basin Characteristics}

Basin characteristics used in describing the magnitude and frequency of flooding are: 1) drainage area (A) which can be described as all contributing drainage upstream from a desired point along a river channel, and 2) average main-channel slope (s). Average main-channel slope was determined from elevations at points 10 and 85 percent of the distance along the channel from the gaging station to the divide.

\section{Determination of Estimating Relations}

Relationships developed herein were determined by the stepbackward multiple regression technique. Streamflow characteristics (2-, 5-, 10-, 25-, 50-, and 100-year flood) or dependent variables were related to basin characteristics. 
First attempts of the regression computation indicated drainage area and average main-channel slope to be significant independent variables in the equation $Q_{T}=a A^{b 1} S^{b 2}$.

However, a plot of the logarithms of the residual

$\left[\left(\log \rho_{T}\left(\right.\right.\right.$ observed) - $\log \varrho_{T}$ (computed)] versus the logarithms of the slope and drainage area indicated nonlinearity.

The basic regression model was again fitted to the array by adjusting the exponent to drainage area based on techniques described by Creager, Justin, and Hinds in their report "Engineering for Dams" (1947). Several attempts were made until the adjustment could be made which would result in the least standard error for the equation $Q_{T}=a A^{b} l^{A c} S^{b}$ and linearity in the area component could be obtained. The same residuals (computed with the adjusted relationship) were plotted on a map of the State to determine any graphic trend. Results showed a random scatter throughout the state thus indicating the relationships to be applicable statewide.

\section{SUMMARY}

Techniques for estimating magnitude and frequency of floods at ungaged Missouri streams given in this report utilize the basic linear regression model with adjustments to independent variable components to achieve linearity. Drainage area and slope proved to be significant basin characteristics and were used in defining the relationships. A plot of residuals on a map indicates statewide applicability of the equations. 


\section{REFERENCES}

Creager, W. P., Justin, J. D., and Hinds, J., 1947, Engineering for dams, volume I: New York, John Wiley, p. 125-126.

Dawdy, D. R., Lichty, R. W., and Bergmann, J. M., 1972, A rainfall-runoff simulation model of estimation of flood peaks for small drainage basins: U.S. Geol. Survey Prof. Paper .506-B, 28 p.

Matthai, H. F., 1968, Magnitude and frequency of floods in the United States, Part 6B, Missouri River below Sioux City, Iowa: U.S. Geol. Survey Water-Supply Paper 1680, 491 p. Patterson, J. L., 1964, Magnitude and frequency of floods in the United States, Part 7, Lower Mississippi River basin: U.S. Geol. Survey Water-Supply Paper 1681, 636 p.

Patterson, J. L., and Gamble, C. R., 1968, Magnitude and frequency of floods in the United States, Part 5, Hudson Bay and Upper Mississippi River basins: U.S. Geol. Survey Water-Supply Paper 1678, 546 p.

Sandhaus, E. H., and Skelton, John, 1968, Magnitude and frequency of Missouri floods: Missouri Geol. Survey and Water Resources rept. 23,276 p.

Searcy, J. K., 1955, Floods in Missouri, magnitude and frequency: U.S. Geol. Survey Circ. 370, 126 p. Skelton, John, and Homyk, Anthony, 1970, A proposed streamflow data program for Missouri: U.S. Geol. Survey open-file rept., $77 \mathrm{p}$. 
U.S. Water Resources Council, 1967, A uniform technique for determining floodflow frequencies: U.S. Water Resources Council Bull. 15, 15 p. 